\title{
Gastric Cronkhite Canada Polyposis
}

National Cancer Institute

\section{Source}

National Cancer Institute. Gastric Cronkhite Canada Polyposis. NCI Thesaurus. Code C7035.

Non-neoplastic polyps that arise from the stomach and are often indistinguishable from hyperplastic polyps. They may be associated with the presence of polyps in other parts of the gastrointestinal tract. Associated clinical signs and symptoms are nail atrophy, alopecia, and hyperpigmentation. 